\title{
A Shock to the System: How Family Businesses Can Survive Covid-19
}

\author{
Tulsi Jayakumar (SP Jain Institute of Management \& Research) \\ Alfredo De Massis (Free University of Bozen-Bolzano)
}

$\begin{array}{lccc}\text { KEYWORDS: } & \text { Family } & \text { Business, } & \text { COVID-19, } \\ \text { \#familybusiness, } & \text { Family } & \text { Business } & \text { Consulting, }\end{array}$

Resilience.

The coronavirus pandemic has had massive repercussions on the global economy and trade. Global economic growth is expected to shrink by about 2 per cent per month, while global trade is expected to fall by 13 percent to 32 percent (Jackson et al., 2020). The virus also threatens the survival of firms across multiple sectors, industries and nations, affecting individuals, economies and society.

Family businesses are especially vulnerable, and they account for an estimated two-thirds of the overall businesses worldwide, 70-90 percent of the annual global GDP and 50-80 percent of the overall jobs in majority of the countries (Family Firm Institute, 2017; De Massis et al., 2018b). Family businesses have a difficult enough time surviving across generations even during normal times. About 30 percent of family businesses survive past the first generation, 13 percent past the second and hardly 3 percent of family businesses survive beyond the third generation (Ward, 1987). The current pandemic is likely to make things worse, especially for small family firms.

We look at the different ways Covid 19 affects the survival of family businesses. Next, we help family businesses assess their ability to survive the pandemic through a $2 \times 2$ matrix, involving the family business system. We call this the Family Business PandemicReadiness Matrix. Finally, we offer strategies to help family businesses tackle the shocks arising out of the pandemic. In doing so, we extend Wenzel, Stanske and Lieberman's (2020) taxonomy of strategic responses to a crisis by applying it to the Family Business PandemicReadiness Matrix.

\section{A 'Cocktail of Shocks'}

Family firms are businesses in which a family has both the ability to influence the vision of the business and the willingness to transfer the business to the next generation of family owners (Chua et al., 1999; Kotlar et al., 2014). They are vulnerable, complex organizations involving several overlapping systems. One of the most influential models of the family business systems, developed by Tagiuri and Davis in 1978 and published in 1996, visualizes the family business system as three interdependent and overlapping sub-systems: business, family and ownership. The pandemic, while a health crisis, can be expected to create a shock within each of these three sub-systems, leading to a strong mix of shocks interacting with one another in a way that can intensify the overall effect. We call this a cocktail of shocks.

\section{Business Sub-system Shocks}

In crises, financially fragile family businesses, especially the smallest ones, experience financial shocks within the business sub-system. Managing liquidity has always been a challenge for small family businesses (De Massis, Audretsch, Uhlaner \& Kammerlander, 2018). While all companies would find their working capital needs going up during a crisis, this need would be particularly severe for small family businesses. They also face another major financial constraint: capital. Most family businesses follow a policy of "zero debt," with little reliance on bank loans or even external investors during normal times, and then find themselves with their backs against the wall financially during a situation in which their profits are already non-existent or negative. Small family businesses may also have poor accounting records and financial practices, which limit their ability to project sales and revenues, assess their break-even point and analyze finances. Without proper accounting records and systems, small family businesses don't have legal recourse to enforce
Copyright $@ 2020$ The Authors. Entrepreneur \& Innovation Exchange is published at EIX.org. This is an open access article under the terms of the Creative Commons Attribution-NoDerivs License, which permits use and distribution in any medium, provided the original work is properly cited and no modifications or adaptations are made. View EIX.org Authorship Terms at https://eix.org/terms
FamilyBusiness ORG 
contracts in crisis times. Besides impeding business growth and profitability, this also reduces their ability to make meaningful decisions.

The lack of a professional management cadre providing a second rung of leadership can also create problems for small family businesses. This not only limits their ability to comprehend and respond to multiple shocks, but also creates the risk of collapse if the senior generation at the top becomes ill.

Risk planning is the final challenge in the business subsystem. Most family businesses are part of extended global supply chains. This makes them as vulnerable as larger firms to global and emerging risks relating to supply chain, markets, partners etc. Such risks could include political risks, geopolitical risks, environmental risks, technological and economic risks (SmithBingham, 2016). However, small family businesses' risk planning is typically less robust than larger firms', putting them at a huge disadvantage. They may have limited risk intelligence, which precludes risk avoidance. Organizational issues in small family businesses, including lack of delegation and focusing on short-term outcomes, may compound problems.

\section{Family and Ownership Sub-systems Shocks}

Family businesses around the world suffer when they believe the myth that businesses can simply be handed over from one generation to the next, without any succession planning. Sometimes this happens when senior-generation incumbents can't give up control, because of their strong attachment to the business, an aversion to ceding power, fear of retirement and their financial position, or the inability to choose between children (De Massis, Chua and Chrisman, 2008; Levinson, 1971). This creates problems for the family and ownership sub-systems.

Older people are especially vulnerable to the coronavirus, and a grave illness that affects the senior leader of the firm can create shocks within the family and ownership sub-systems. As the senior generation succumbs to the virus, or even reduces its involvement in the business due to health-related advisories, we may witness multiple changes in the firm's financial performance arising from changes -- both cultural and psychological -- in the family and ownership subsystems.
Even during normal times, "critical incidents," such as a change in ownership and the ascendance of the next generation, impact the risk-taking intent, the strength of family bonds and the commitment towards the founder's vision. Family businesses, even those whose sales, assets or number of employees are small, may actually involve large business families with complex multigenerational involvement. A pandemic crisis could magnify the impact of such critical incidents, make the shocks to the family and ownership sub-systems even worse, and significantly weaken family bonds and social ties. This would ultimately impact the economic wealth of the family business.

The pandemic may also make tough business decisions, including layoffs, financially or economically necessary. Most family businesses depend on loyal employees who have been with them for a long time, and are consequently in the older, vulnerable age groups. If not managed sensitively, laying them off would be devastating to them and erode the family social capital. Similarly, business actions such as "price gouging," or compromising on quality to make fast profits during scarcities induced by the pandemic, risk severe backlash from consumer groups and reputational loss for the family.

\section{THE FAMILY BUSINESS PANDEMIC- READINESS MATRIX}

A family business' ability to withstand these multiple shocks and survive the pandemic crisis would be based on the resilience of its three sub-systems: business, family and ownership. We've created a matrix that combines the business sub-system resilience (along the $x$-axis) with the family and ownership sub-system resilience (along the $y$-axis) to evaluate the various types of family business systems and their readiness and ability to survive a pandemic crisis. Each of these dimensions -- business sub-system resilience and family and ownership sub-system resilience -- can range from low to high. We term this resultant matrix, incorporating both the elements, the "Family Business Pandemic-Readiness Matrix" (Table 1) ${ }^{[1]}$. 
Table 1: The Family Business Pandemic-Readiness Matrix Ability to survive a pandemic crisis

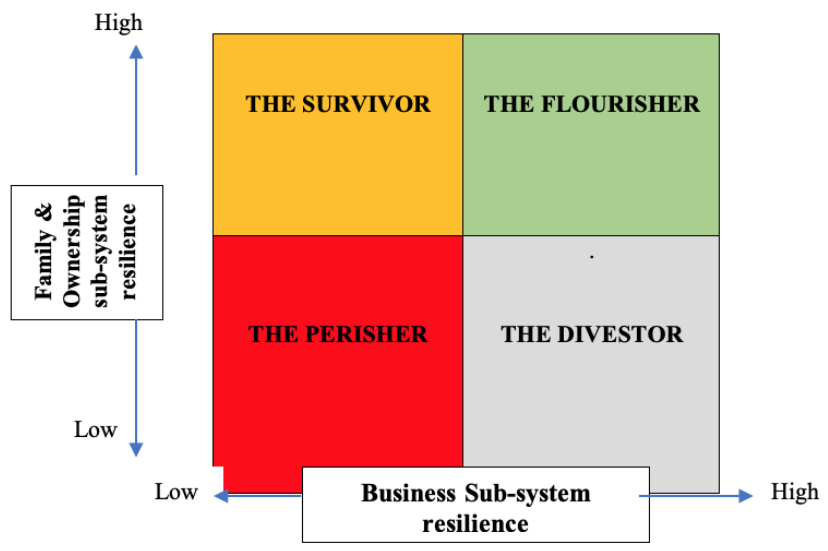

Based on this matrix, we can distinguish among four types of family businesses and their ability to survive the crisis.

Type 1: The Perishers: In the lower left-hand corner are family businesses with low business and family \& ownership resilience: the "Perishers." Such family businesses will likely perish. We can visualize such family businesses as the most vulnerable groups among various forms of business organizations, similar to those vulnerable population segments most at risk of succumbing to the virus.

Type 2: The Divestors: The grid at the bottom righthand corner, with high business resilience but low family and ownership resilience, represents the "Divestors." These family businesses may be in a particularly lucrative or niche area, with high business resilience. Some examples might be companies that make sanitizers or Personal Protective Equipment (PPE), or provide other goods or services required during the pandemic. This category may be able to withstand the pandemic on account of the high business resilience in the short-term, but over a period will prefer to divest its stake and exit the business.

Type 3: The Survivors: The top left quadrant marks the group of "Survivors." While these family businesses may possess low business resilience, a combination of strong family and ownership characteristics can help such family businesses persevere and/or pivot and secure their future.

Type 4: The Flourishers (Innovators): The top right corner represents the "Flourishers." These family businesses are a happy amalgamation of strong business and family and ownership sub-systems. They would use their own innate strength and high resilience to innovate their way out of the crisis.

\section{STRATEGIES FOR FAMILY BUSINESS SURVIVAL DURING THE PANDEMIC}

Wenzel, Stanske and Lieberman (2020) identify four strategic responses of firms to a crisis: retrenchment, persevering, innovating, and exit. We apply these strategies to the family business taxonomy derived in the previous section, while adding another strategy: divestment. Family businesses, other than perishers, will use a mix of exit/retrenchment, perseverance, divestment and innovation strategies to overcome the pandemic. The relevant mix will depend on the interplay of the business as well as the family and ownership resilience.

1. Exit / Retrenchment strategy. Exit refers to the deliberate discontinuation of a firm's business activities. This would likely be the strategy of the Perishers, plagued as they are by low levels of family and ownership as well as business resilience. The pandemic may bring out the vulnerabilities of this segment of family businesses, which may not have been evident before. Such businesses may also adopt retrenchment strategies, resorting to costcutting measures that potentially reduce the scope of their business activities. These include strategies such as downsizing and retrenching labor in their struggle for survival, eroding family social capital and ultimately affecting firm financial performance.

2. Perseverance strategy. Perseverance refers to the firm maintaining the status quo of its business activities in times of crisis. Family businesses with low business resilience, but with strong network ties with their vendors, dealers and customers and strong social standing, may be able to tide over the crisis. The Survivor group may be expected to exhibit a perseverance strategy.

3. Divestment strategy: Divestment - eliminating a portion of their business -- is a particular form of retrenchment used by businesses while downsizing the scope of their business 
activities. Divestors may sell-off existing profitable businesses during a pandemic because the family and ownership sub-systems are not resilient. Thus, the lack of adequate succession planning, together with the vulnerability of a founder/ senior generation member(s) to Covid, may trigger divestment, even despite having strong business resilience.

4. Innovation strategy: The strategy of innovation would be likely pursued by the Flourishers - a group of family businesses that encourage transgenerational entrepreneurship by adopting new business models and or continuous innovations. Such businesses exhibit both the ability and willingness to innovate their way out of the crisis, by possessing both strong business resilience, and more importantly, strong family and ownership resilience, which allows for a culture of innovation.

A pivoting strategy may also be pursued by Survivors, where low business resilience is accompanied by high family and ownership resilience. Thus, for instance, even as the real estate business has taken a big hit in several economies, the Work From Home (WFH) norms that appear to be the new reality may lead to greater demand for small office and commercial spaces. This may require that a family-owned realtor company shift its focus from selling homes to a different business model. With strong family support, a family firm can pivot from its traditional business building brick-andmortar structures to one dealing in pre-fabricated cabins.

\section{CONCLUSION}

COVID-19 will impact family businesses in many ways, and they will need to adopt multiple strategies to overcome the pandemic. However, the success of such strategies depends on the resilience of the family business system and its three overlapping subsystems for family, business and ownership. Given the institutional environments, family businesses will need to focus on developing and building business resilience on the one hand, and family and ownership resilience on the other, to withstand such shocks. In fact, epidemics and pandemics, besides acting as standalone risks, also highlight the need for family businesses to assess and strengthen their three sub-systems before a crisis arises and makes them vulnerable.
[1] We assume a particular intensity of virus transmission, while using the matrix as a tool for assessing the ability of the family business to survive the crisis. Any increase in the intensity of the virus transmission or mutations in the virus would add to the complexities of survival. Further, while this matrix has been created for assessing the family business readiness to survive a virus shock, it may equally apply to a family business' resilience to other systemic shocks, impacting various parts of the family business sub-system differentially.

\section{REFERENCES}

Chua, J. H., J. J. Chrisman, and P. Sharma (1999). Defining the Family Business by Behavior. Entrepreneurship Theory and Practice 23(4), 19-39.

De Massis A., Chua J.H., Chrisman J.J. (2008). Factors Preventing Intra-Family Succession. Family Business Review, 21(2), 183-199.

De Massis, A., Audretsch, D., Uhlaner, L., \& Kammerlander, N. (2018a). Innovation with limited resources: Management lessons from the German Mittelstand. Journal of Product Innovation Management, 35(1,) 125-146.

De Massis A., Frattini F., Majocchi A., Piscitello L. (2018b). Family firms in the global economy: Toward a deeper understanding of internationalization determinants, processes and outcomes. Global Strategy Journal, 8(1), 3-21.

De Massis A., Kotlar J., Chua J.H., Chrisman J.J. (2014). Ability and Willingness as Sufficiency Conditions for Family-Oriented Particularistic Behavior: Implications for Theory and Empirical Studies. Journal of Small Business Management, 52(2), 344-364.

Family Firm Institute. (2017). Global data points.

Jackson, J.K., Weiss, M.A., Schwarzenberg, A.B., \& Nelson, R.M. (2020). Global Economic Effects of Covid-19, Congressional Research Service, R46270, May https://fas.org/sgp/crs/row/R46270.pdf (https://fas.org/sgp/crs/row/R46270.pdf) .

Levinson, H. (1971). Conflicts that plague family businesses. Harvard Business Review, 49, 90-98.

Smith-Bingham, R. (2016). Assessing emerging risks:

\section{Notes}


Obstacles and opportunities. Brink News, April 12, https://www.brinknews.com/assessing-emerging-risksobstacles-and-opportunities/

(https://www.brinknews.com/assessing-emerging-risksobstacles-and-opportunities/)

Tagiuri R. \& Davis J. (1996). Bivalent attributes of the family firm. Family Business Review, 9(2), 199-208.

Ward, J. (1987). Keeping the family business healthy, San Francisco, CA: Jossey-Bass.

Wenzel, M., Stanske, S., \& Lieberman, M.B. (2020). Strategic responses to crisis. Strategic Management Journal. In press. Doi: 10.1002/smj.3161 